\title{
KEPUTUSAN PEMBELIAN SEPEDA MOTOR HONDA MELALUI PROMOSI PENJUALAN DAN LOKASI PADA PT BINTANG MOTOR JAYA JAKARTA
}

\author{
Eigis Yani Pramularso \\ eigis.eyp@bsi.ac.id \\ Universitas Bina Sarana Informatika
}

\begin{abstract}
ABSTRAK
Perusahaan sebagai penyedia produk terus berupaya membuat konsumen tertarik sehingga mendorong terjadinya keputusan pembelian. Keputusan pembelian diupayakan semakin meningkat diantaranya dengan memberikan promosi penjualan yang sesuai dan menentukan lokasi usaha yang tepat dan strategis. Tujuan penelitian ini adalah untuk mengetahui pengaruh promosi penjualan dan lokasi terhadap keputusan pembelian sepeda motor Honda pada PT Bintang Motor Jaya Jakarta. Pada penelitian ini digunakan data kuantitatif dengan membagikan angket kepada responden yang dituju. Metode pengambilan sampel yang digunakan adalah teknik non probability sampling berupa accidental sampling dengan jumlah sampel yang diperoleh sebanyak 79 responden. Pada penelitian ini analisis regresi digunakan dalam analisis datanya. Penelitian hasilnya menunjukkan promosi penjualan dan lokasi secara simultan berpengaruh positif dan signifikan tehadap keputusan pembelian, promosi penjualan secara parsial berpengaruh positif dan signifikan tehadap keputusan pembelian, dan lokasi secara parsial berpengaruh positif dan tidak signifikan tehadap keputusan pembelian sepeda motor Honda pada PT Bintang Motor Jaya Jakarta.
\end{abstract}

Kata Kunci: Promosi Penjualan, Lokasi, Keputusan Pembelian

\begin{abstract}
ABSTRAK
The company as a product provider continues to strive to attract consumers so as to encourage purchase decisions. Purchasing decisions are sought to increase, including by providing appropriate sales promotions and determining the right and strategic business location. The purpose of this study was to determine the effect of sales promotion and location on purchasing decisions for Honda motorcycles at PT Bintang Motor Jaya Jakarta. In this study, quantitative data was used by distributing questionnaires to the intended respondents. The sampling method used is a non-probability sampling technique in the form of accidental sampling with a total sample of 79 respondents. In this study, regression analysis was used in the data analysis. The results of the research show that sales promotion and location simultaneously have a positive and significant effect on purchasing decisions, sales promotions partially have a positive and significant effect on purchasing decisions, and location partially has a positive and insignificant effect on purchasing decisions for Honda motorcycles at PT Bintang Motor Jaya Jakarta.
\end{abstract}

Keywords: Sales Promotion, Location, Purchase Decision 


\section{PENDAHULUAN}

Perkembangan industri transportasi terus berubah sehingga perlu menjadi perhatian penting bagi pelaku usaha dibidang usaha tersebut. Pelaku usaha sebagai produsen dan distributor harus terus beradaptasi dan lebih kreatif agar mampu bersaing dengan baik dalam ketatnya persaingan sekarang ini. Adaptasi dan kreativitas yang dilakukan oleh pelaku usaha tersebut tentu dilakukan dengan melihat situasi dan kondisi pasar terutama perhatian terhadap proses keputusan konsumen dalam memilih produk yang dipilihnya. Keputusan pembelian yang terjadi menjadi tanda kunci keberhasilan suatu produk dapat diterima oleh pengguna. Menjadi tantangan tersendiri bagaimana produsen untuk melakukan usaha maksimal sehingga keputusan pembelian tersebut jumlahnya terus meningkat. Produsen bisa memahami dan melakukan kebijakan terkait faktor yang dapat menentukan keputusan pembelian dapat terjadi. Faktor-faktor yang menjadi pendorong bagaimana adanya keputusan pembelian dapat dikaitkan dengan faktor pemasaran seperti harga yang ditetapkan, kualitas produk yang diciptakan oleh produsen, promosi yang dilakukan, dan penentuan lokasi disamping ada faktor lingkungan sosial budaya dan faktor psikologis (Septiana, 2017).

Promosi penjualan menjadi salah satu komunikasi penting dalam pengenalan informasi dan pengingat bagi konsumen. Produsen dapat memilih sarana promosi penjualan yang sesuai dengan produk dan kemampuan produsen. Promosi penjualan yang dilakukan tentu dapat dilakukan dengan berbagai bentuk promosi yang dapat menarik perhatian konsumen. Adanya promosi penjualan diharapkan pula dapat menimbulkan ketertarikan konsumen yang tadinya belum tertarik dengan produk yang ada. Menurut (Ye and Zhang, 2014) promosi penjualan merupakan perangkat bagi para pemasar dan salah satu elemen penting dalam bauran pemasaran. Menurut (Chang, 2017) promosi penjualan dan niat pembelian menunjukkan hubungan yang signifikan. Lokasi menjadi salah faktor penting bagi konsumen dalam menentukan pilihan produk. Lokasi yang dekat konsumen dan terjangkau dapat menjadi perhatian bagi produsen dalam menentukan pemilihan lokasi. Akses lokasi yang mudah dan strategis menjadi pilihan utama konsumen dalam mencari produk yang akan dibelinya. Menurut (Zainab, 2018) lokasi menjadi tempat dimana perusahaan beroperasi dan menghasilkan produk berupa barang dan jasa, serta pemilihan lokasi perusahaan akan menentukan keberhasilan suatu usaha.

PT Bintang Jaya Motor yang menjadi salah satu diler yang menjual sepeda motor merek Honda tentunya tidak lepas perhatian terkait keputusan pembelian yang prosesnya 
Eigis Yani Pramularso, Keputusan Pembelian Sepeda Motor Honda

melalui tahapan yang ada. Tahapan dalam keputusan pembelian dari pengenalan, pemberian suatu informasi, memberikan pilihan alternatif, keputusan pembelian, dan kegiatan setelah pembelian dilakukan tentu menjadi permasalahan sekaligus peluang bagi PT Bintang Jaya Motor sehingga perusahaan berupaya tetap melayani, bertahan, dan bisa unggul di persaingan. PT Bintang Jaya Motor dengan caranya sendiri terus berupaya melakukan kreativitas sehingga produk yang ditawarkan tetap diperhatikan dan diterima konsumen seperti menentukan lokasi usaha yang strategis maupun terus melakukan serangkaian promosi penjualan dengan pilihan promosi penjualan yang ada seperti pemberian hadiah langsung, melakukan undian berhadiah, adanya paket harga yang menarik yang pada akhirnya konsumen diharapkan melakukan keputusan pembelian.

Penelitian yang lakukan oleh (Rohmah and Lubis, 2018) menunjukkan bahwa keputusan pembelian dipengaruhi oleh promosi penjualan ada situs online elevania. Dalam penelitian (Prasetio and Rismawati, 2018) juga menghasilkan penelitian bahwa keputusan pembelian di Toserba Borma Cabang Dakota juga dipengaruhi oleh promosi penjualan yang telah dilakukan. Penelitian oleh (Anggraini and Melinda, 2018) menunjukkan bahwa promosi penjualan dan word of mouth yang dilakukan pada jasa Dreamland Decoration memiliki pengaruh signifikan terhadap keputusan pembelian konsumen.

Penelitian oleh (Rizal, Adam and Ibrahim, 2017) menunjukkan bahwa lokasi, harga, dan desain memiliki pengaruh signifikan secara simultan dan parsial terhadap keputusan pembelian rumah di kota Banda Aceh. (Istanti, 2018) penelitiannya mengemukakan bahwa keputusan pembelian yang terjadi di Indomaret Genteng kota Surabaya secara parsial dan simultan dipengaruhi oleh promosi dan dan lokasi. (Yan, Repi and Lumanauw, 2018) dalam penelitiannya bahwa keputusan pembelian pada PT Tridjaya Mulia Sukses dipengaruhi signifikan secara parsial dan simultan dari faktor promosi penjualan dan lokasi. Penelitian dari (Abdullah, 2018) yang dilakukan pada Genesis Coffee di kota Bandung diketahui bahwa keputusan pembelian secara parsial dan simultan dipengaruhi promosi penjualan dan lokasi dengan hasil positif dan signifikan.

Promosi penjualan merupakan alat insentif jangka pendek yang rancangannya untuk memberikan rangsangan kepada konsumen atau pedagang agar lebih cepat dan lebih besar dalam melakukan pembelian suatu produk atau jasa tertentu (Kotler and Keller, 2018). Promosi penjualan memiliki fungsi utama untuk melakukan komunikasi dengan konsumen dan menyentuh hati konsumen tersebut (Chang, 2017). Menurut Neslin dalam (Ye and Zhang, 2014) sebagian besar penelitian memiliki kesimpulan bahwa 
promosi penjualan yang ada dapat memberikan dampak signifikan meskipun pengaruh berbagai komponen didalamnya mungkin berbeda terhadap perilaku konsumen dan keputusan pembelian. Karakteristik yang dimiliki oleh promosi penjualan dapat berupa komunikasi, insentif dan ajakan (Priansa, 2017). Lokasi sebagai bagian dalam bauran pemasaran adalah faktor yang sangat penting dimana pada sebuah gerai atau toko akan lebih sukses dengan memilih lokasi yang strategis dan tepat dibandingkan dengan gerai yang kurang strategis dalam penentuan lokasinya (Fure, 2013). Lokasi memiliki indikator diantaranya lokasi yang strategis, ketersediaan atau hal tersedianya lahan parkir, lokasi dengan dilalui banyak alat transportasi, memiliki tempat yang cukup luas dan alat transportasi yang mudah dijangkau (Fure, 2013).

Keputusan pengertiannya sebagai pemilihan tindakan dari pilihan dua atau lebih alternatif yang ada dan umumnya konsumen mengkuti proses dalam pangambilan keputusan dalam membeli suatu produk (Rossanty, Nasution and Ario, 2018). Menurut (Priansa, 2017) keputusan pembelian memiliki dimensi berupa pilihan berupa produk, pilihan merek, pilihan saluran pembelian, jumlah pembelian, dan waktu pembelian. Paparan latar belakang di atas membuat ketertarikan untuk meneliti lebih lanjut tentang keputusan pembelian konsumen yang terkait dengan promosi penjualan dan lokasi. Tujuan dalam penelitian ini adalah untuk mengetahui pengaruh promosi penjualan dan lokasi terhadap keputusan pembelian sepeda motor Honda PT Bintang Jaya Motor Jakarta baik secara bersama-sama maupun secara sendiri-sendiri.

\section{METODE}

Penelitian yang dilakukan menggunakan pendekatan kuantitatif. Penelitian ini dilakukan pada diler atau pedagang penyalur resmi sepeda motor Honda yaitu PT Bintang Motor Jaya Jakarta. Populasi dalam penelitian ini adalah seluruh konsumen yang memutuskan melakukan pembelian sepeda motor Honda di PT Bintang Motor Jaya Jakarta. Untuk teknik pengambilan sampel menggunakan accidental sampling sebagai salah satu teknik non probability sampling dengan sampel yang diperoleh sebanyak 79 orang yang menjawab sejumlah pertanyaan yang dicantumkan dalam angket dengan lengkap. Analisis data yang digunakan memakai regresi dengan teknik olah data yang dilakukan menggunakan SPSS 25. Menurut (Juliandi et al., 2016) tujuan analisis regresi untuk melakukan prediksi adanya perubahan nilai variabel dependen yang diakibatkan adanya pengaruh dari nilai variabel independen atau variabel bebas. Ada tiga variabel yang digunakan dalam penelitian ini yaitu variabel promosi penjualan dan variabel lokasi 
Eigis Yani Pramularso, Keputusan Pembelian Sepeda Motor Honda

sebagai variabel bebas dan sebagai variabel terikatnya adalah variabel keputusan pembelian.

Analisis data dilakukan setelah dilakukan suatu penyebaran angket dalam metode pengumpulan datanya dan selanjutnya dilakukan uji validitas dan uji reliabilitas. Dalam penelitian ini validitas menggunakan korelasi item total yaitu dengan mengkorelasikan skor butir pertanyaan dengan skor total sedangkan uji reliabilitas menggunakan croncbac'hs alpha untuk mengetahui sejauh mana dapat terpercayanya suatu pengukuran. Validitas dikatakan tepat atau valid jika nilai probabilitas yang dihasilkan $\leq$ dari probabilitas yang telah ditetapkan yaitu 0,05 atau Sig. (2-tailed) $\leq \boldsymbol{\alpha} 0,05$ sedangkan instrumen disebut dapat dipercaya atau reliabel jika koefisien reliabilitas nilainya diatas 0,6 (Juliandi et al., 2016).

\section{HASIL DAN PEMBAHASAN}

Hasil uji validitas promosi penjualan yang telah dilakukan dengan 7 butir pertanyaan diperoleh data berikut:

Tabel 1

Uji validitas promosi penjualan

\begin{tabular}{cc}
\hline No. & rhitung \\
\hline 1 & 0,434 \\
\hline 2 & 0,527 \\
\hline 3 & 0,622 \\
\hline 4 & 0,625 \\
\hline 5 & 0,757 \\
\hline 6 & 0,687 \\
\hline 7 & 0,492
\end{tabular}

Sumber: Pengolahan data penelitian, 2021

Berikut hasil uji validitas variabel lokasi dengan 8 butir pertanyaan yang terdapat dalam angket:

Tabel 2

Uji validitas lokasi

\begin{tabular}{cc}
\hline No. & $\mathrm{R}_{\text {hitung }}$ \\
\hline 1 & 0,718 \\
\hline 2 & 0,761 \\
\hline 3 & 0,826 \\
\hline 4 & 0,792 \\
\hline 5 & 0,836 \\
\hline 6 & 0,836 \\
\hline 7 & 0,853 \\
\hline 8 & 0,818 \\
\hline
\end{tabular}

Sumber: Pengolahan data penelitian, 2021 
Uji validitas keputusan pembelian dengan 6 pertanyaan dapat dilihat pada tabel dibawah ini:

Tabel 3

Uji validitas keputusan pembelian

\begin{tabular}{cc}
\hline No. Butir pertanyaan & rhitung \\
\hline 1 & 0,662 \\
\hline 2 & 0,702 \\
\hline 3 & 0,620 \\
\hline 4 & 0,720 \\
\hline 5 & 0,670 \\
\hline 6 & 0,583 \\
\hline
\end{tabular}

Sumber: Pengolahan data penelitian, 2021

Berdasarkan hasil perhitungan validitas di tabel 1, tabel 2, dan tabel 3 untuk hasil uji validitas variabel promosi penjualan, variabel lokasi, dan variabel keputusan pembelian diketahui bahwa semua butir pertanyaan untuk ketiga variabel tersebut dinyatakan seluruhnya tepat atau valid karena semua nilai hitung probabilitas $\leq$ nilai probabilitas 0,05 atau Sig. (2-tailed) $\leq \boldsymbol{\alpha} 0,05$.

Berikut ditunjukkan hasil uji reliabilitas dalam tabel di bawah ini:

Tabel 4

Uji reliabilitas

\begin{tabular}{lc}
\hline \multicolumn{1}{c}{ Variabel } & Cronbach's Alpha \\
\hline Promosi penjualan & 0,687 \\
\hline Lokasi & 0,917 \\
\hline Keputusan pembelian & 0,740 \\
\hline
\end{tabular}

Sumber: Pengolahan data penelitian, 2021

Uji reliabilitas dengan cronbach's alpha variabel promosi penjualan, variabel lokasi, dan variabel keputusan pembelian yang ditunjukkan pada tabel 4 dikatakan semuanya reliabel dengan masing-masing nilai yang dihasilkan melebihi standar yaitu lebih besar dari nilai 0,60 . 
Eigis Yani Pramularso, Keputusan Pembelian Sepeda Motor Honda

Uji normalitas hasilnya dapat diketahui melalui gambar berikut:

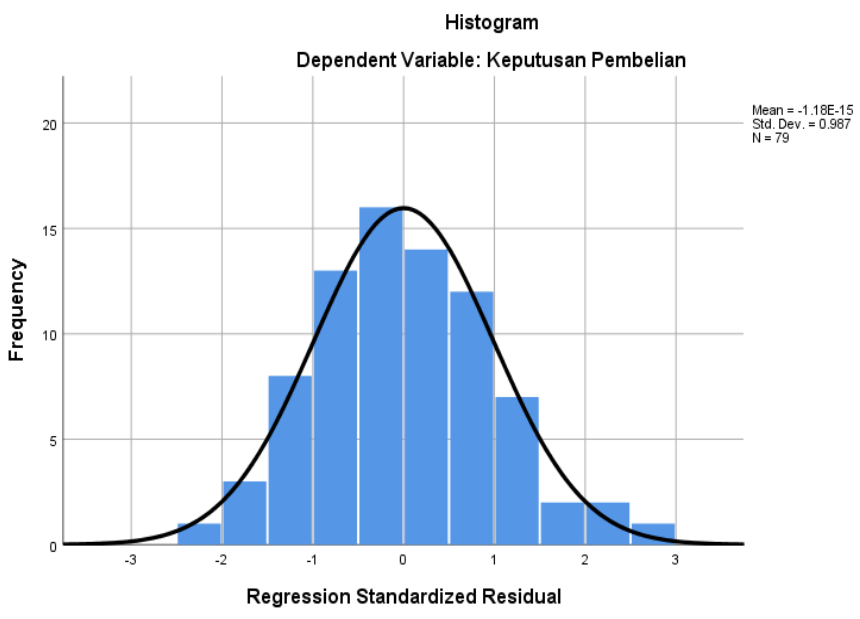

Sumber: Pengolahan data penelitian, 2021

Gambar 1

Histogram

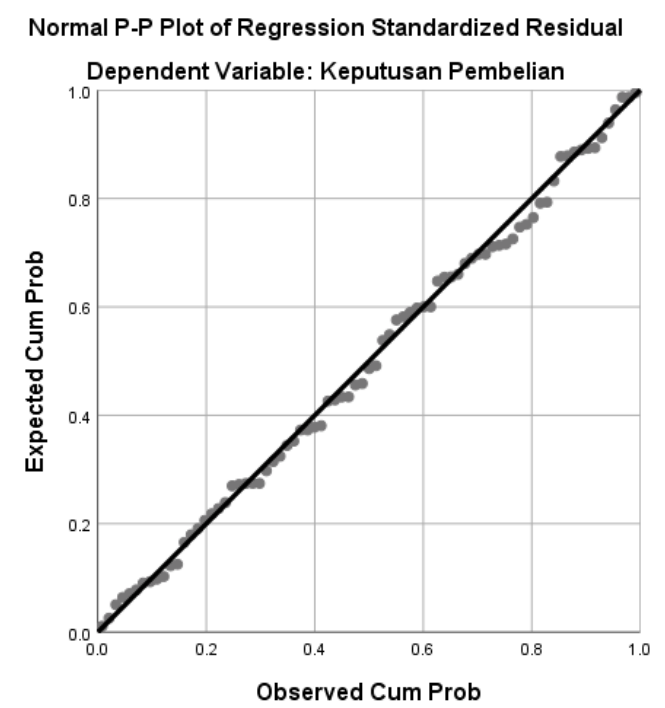

Sumber: Pengolahan data penelitian, 2021

Gambar 2

Normal Probability Plot

Berdasarkan gambar 1 histogram terlihat bahwa mengikuti distribusi normal dan gambar 2 dengan Normal Probability Plot diketahui data memiliki distribusi normal dengan titik-titik ada digaris diagonal serta searah garis. 
Berikut adalah tabel hasil uji liniearitas yang dilakukan:

\section{Tabel 5}

Hasil uji linearitas promosi penjualan dengan keputusan pembelian

\section{ANOVA Table}

\begin{tabular}{|c|c|c|c|c|c|c|c|}
\hline & & & $\begin{array}{l}\text { Sum of } \\
\text { Squares }\end{array}$ & Df & $\begin{array}{l}\text { Mean } \\
\text { Square }\end{array}$ & $\mathrm{F}$ & Sig. \\
\hline \multirow{5}{*}{$\begin{array}{l}\text { Keputusan } \\
\text { Pembelian } \\
* \quad \text { Promosi } \\
\text { Penjualan }\end{array}$} & Between & (Combined) & 413.678 & 13 & 31.821 & 9.726 & .000 \\
\hline & Groups & Linearity & 381.995 & 1 & 381.995 & 116.749 & .000 \\
\hline & & $\begin{array}{l}\text { Deviation } \\
\text { from } \\
\text { Linearity }\end{array}$ & 31.682 & 12 & 2.640 & .807 & .642 \\
\hline & Within $\mathrm{G}$ & oups & 212.677 & 65 & 3.272 & & \\
\hline & Total & & 626.354 & 78 & & & \\
\hline
\end{tabular}

Sumber: Pengolahan data penelitian, 2021

Tabel 6

Uji linearitas lokasi dengan keputusan pembelian

\begin{tabular}{|c|c|c|c|c|c|c|c|}
\hline \multicolumn{8}{|c|}{ ANOVA Table } \\
\hline & & & $\begin{array}{l}\text { Sum of } \\
\text { Squares }\end{array}$ & Df & $\begin{array}{c}\text { Mean } \\
\text { Square }\end{array}$ & $\mathrm{F}$ & Sig. \\
\hline \multirow{5}{*}{$\begin{array}{l}\text { Keputusan } \\
\text { Pembelian } \\
\text { * Lokasi }\end{array}$} & \multirow{3}{*}{$\begin{array}{l}\text { Between } \\
\text { Groups }\end{array}$} & (Combined) & 34.764 & 16 & 2.173 & .228 & .999 \\
\hline & & Linearity & 2.487 & 1 & 2.487 & .261 & .612 \\
\hline & & $\begin{array}{l}\text { Deviation } \\
\text { from } \\
\text { Linearity }\end{array}$ & 32.277 & 15 & 2.152 & .226 & .999 \\
\hline & \multicolumn{2}{|c|}{ Within Groups } & 591.590 & 62 & 9.542 & & \\
\hline & \multicolumn{2}{|l|}{ Total } & 626.354 & 78 & & & \\
\hline
\end{tabular}

Sumber: Pengolahan data penelitian, 2021

Berdasarkan tabel 5 dan tabel 6 diketahui ada linearitas antara promosi penjualan dan keputusan pembelian dengan nilai Sig baris Deviation from Linearity adalah 0,642 lebih besar angkanya dari 0,05. Lokasi dan keputusan pembelian juga ada linearitas dengan nilai Sig baris Deviation from Linearity adalah 0,999 lebih besar dari angka 0,05.

Uji multikolinearitas dapat diihat pada tabel berikut:

Tabel 7

Uji multikolinearitas

\begin{tabular}{lcrr}
\hline \multicolumn{1}{c}{ Variabel Independent } & Tolerance & VIF & \\
\hline Promosi Penjualan &, 998 & 1,002 \\
\hline Lokasi &, 998 & 1,002 \\
\hline
\end{tabular}

Sumber: Pengolahan data penelitian, 2021 
Eigis Yani Pramularso, Keputusan Pembelian Sepeda Motor Honda

Berdasarkan tabel 7 tidak terdapat multikolinearitas antara variabel promosi penjualan dan variabel lokasi dengan nilai tolerance lebih kecil dari 1 dan nilai VIF juga dekat dengan 1.

Untuk uji heteroskedastisitas dapat terlihat dari gambar berikut:

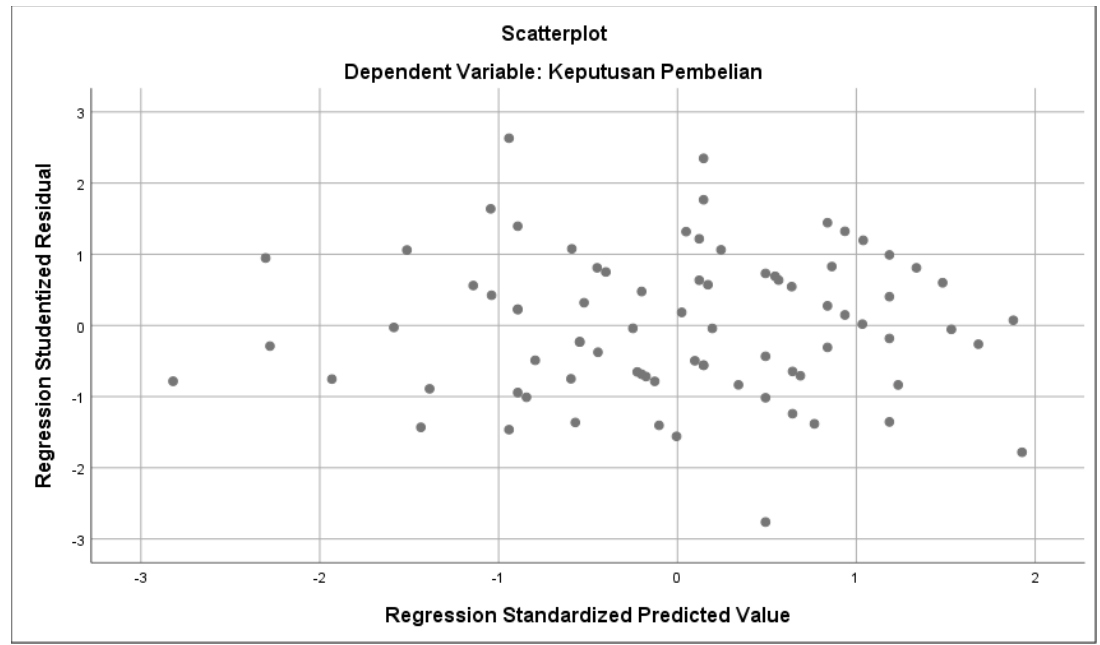

Sumber: Pengolahan data penelitian, 2021

Gambar 3

Uji heteroskedastisitas

Berdasarkan uji heteroskedastisitas di gambar 2 dapat diketahui titik atau point pada grafik tersebar acak di sumbu $Y$ baik diatas atau dibawah angka 0 sehingga dikatakan tidak terdapat heteroskedastisitas pada penelitian ini.

Berikut adalah hasil koefisien korelasi dan koefisien determinasi yang ditunjukkan pada tabel dibawah ini:

Tabel 8

Hasil model summary

\begin{tabular}{|c|c|c|c|c|c|c|c|c|}
\hline \multicolumn{9}{|c|}{ Model Summary ${ }^{b}$} \\
\hline \multirow{2}{*}{$\begin{array}{l}\text { Mo } \\
\text { del }\end{array}$} & \multirow[t]{2}{*}{$\mathrm{R}$} & \multirow{2}{*}{$\begin{array}{l}\mathrm{R} \\
\text { Squa } \\
\text { re }\end{array}$} & \multirow{2}{*}{$\begin{array}{l}\text { Adjusted } \\
\text { R Square }\end{array}$} & \multirow{2}{*}{$\begin{array}{l}\text { Std. Error } \\
\text { of the } \\
\text { Estimate }\end{array}$} & \multicolumn{4}{|c|}{ Change Statistics } \\
\hline & & & & & $\begin{array}{l}\text { R Square } \\
\text { Change }\end{array}$ & F Change df1 & $\mathrm{df} 2$ & $\begin{array}{l}\text { Sig. F } \\
\text { Change }\end{array}$ \\
\hline 1 & $.787^{\mathrm{a}}$ & 619 & .609 & 1.771 & .619 & 61.827 & 76 & .000 \\
\hline
\end{tabular}

a. Predictors: (Constant), Lokasi, Promosi Penjualan

b. Dependent Variable: Keputusan Pembelian

Sumber: Pengolahan data penelitian, 2021

Berdasarkan tabel 8 dapat terlihat bahwa koefisien korelasi ditunjukkan dengan angka 0,787 yang artinya bahwa antara promosi penjualan dan lokasi dengan keputusan pembelian di PT. Bintang Motor Jaya Jakarta memiliki hubungan tinggi atau kuat. Untuk Koefisien determinasi angkanya dengan R Square 0,619 menunjukkan kontribusi untuk keputusan pembelian di PT Bintang Motor Jaya Jakarta dari promosi penjualan dan lokasi sebesar $61,9 \%$ sisanya $38,1 \%$ dipengaruhi variabel lain diluar penelitian ini seperti 
kualitas produk dan harga.

Tabel dibawah adalah hasil uji persamaan regresi yang telah dilakukan beserta hasil perhitungan uji t:

Tabel 9

Hasil persamaan linear regresi berganda dan hasil uji t

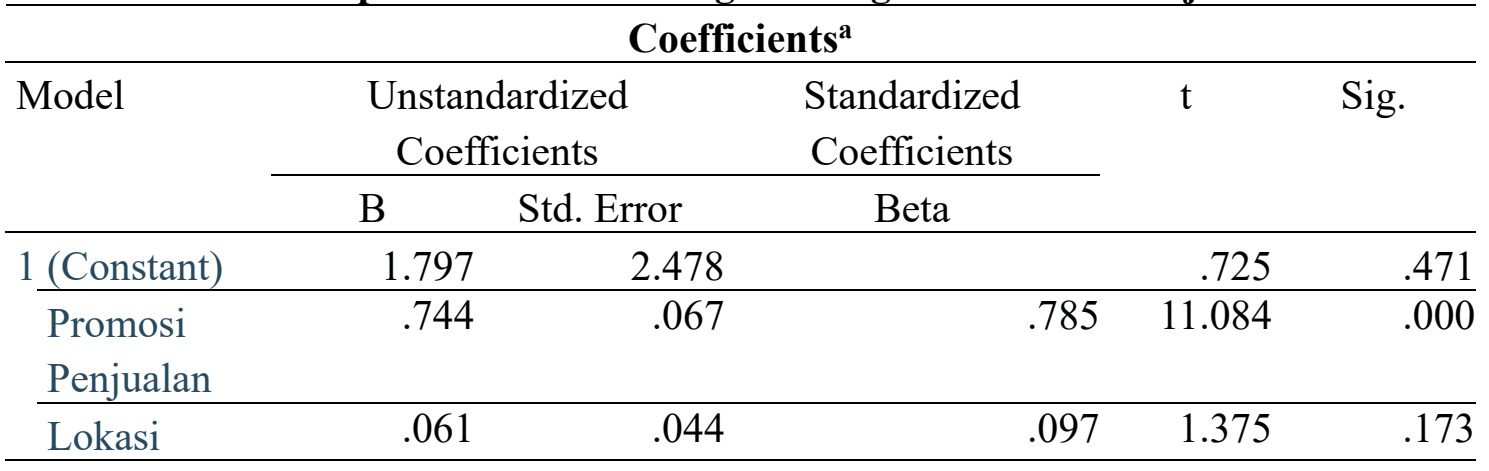

a. Dependent Variable: Keputusan Pembelian

Sumber: Pengolahan data penelitian, 2021

Berdasarkan tabel 9 hasil koefisien regresi variabel promosi penjualan dan variabel lokasi adalah positif dengan persamaan regresi linier berganda berikut ini:

$$
\mathrm{Y}=1,797+0,744 \mathrm{X}_{1}+0,061 \mathrm{X}_{2}
$$

Hasil perhitungan dapat diketahui pula bahwa t hitung kualitas pelayanan adalah 11,084 dengan nilai sig 0,001, berarti dengan signifikan secara parsial keputusan pembelian dipengaruhi oleh promosi penjualan. Sedangkan t hitung lokasi angkanya 1,375 dengan nilai sig 0,173 sehingga secara parsial lokasi tidak memiliki pengaruh signifikan terhadap keputusan pembelian.

Tabel 10

Hasil uji regresi linear berganda

\begin{tabular}{llrrrrr}
\hline \multicolumn{7}{c}{ ANOVA $^{\text {a }}$} \\
Model & $\begin{array}{l}\text { Sum of } \\
\text { Squares }\end{array}$ & Df & Mean Square & F & Sig. \\
\hline \multirow{2}{*}{1} & 387.927 & 2 & 193.964 & 61.827 & $.000^{\mathrm{b}}$ \\
\cline { 2 - 7 } & Regression & 238.427 & 76 & 3.137 & & \\
\cline { 2 - 7 } & Residual & 626.354 & 78 & & & \\
\cline { 2 - 7 } & Total & 6 &
\end{tabular}

a. Dependent Variable: Keputusan Pembelian

b. Predictors: (Constant), Lokasi, Promosi Penjualan

Sumber: Pengolahan data penelitian, 2021

Berdasarkan tabel 10 ditunjukkan angka F hitung sebesar 61,827 dengan nilai sig 0,000. Berarti, promosi penjualan dan lokasi secara bersama-sama memiliki pengaruh signifikan terhadap keputusan pembelian sepeda motor Honda di PT Bintang Motor Jaya Jakarta. 
Eigis Yani Pramularso, Keputusan Pembelian Sepeda Motor Honda

Promosi penjualan dan lokasi memiliki pengaruh positif dan signifikan terhadap keputusan pembelian. Penelitian yang sama dan hasilnya memiliki kesesuaian yaitu penelitian oleh (Yan, Repi and Lumanauw, 2018) dan (Abdullah, 2018). Hasilnya dapat memberi gambaran bahwa promosi penjualan dan lokasi secara bersama-sama memberikan pengaruh terhadap keputusan pembelian. Persamaan regresi yang hasilnya positif menjelaskan bahwa jika promosi penjualan dan lokasi di PT Bintang Motor Jaya semakin baik maka keputusan pembelian yang terjadi juga mengarah ke arah semakin baik. Promosi penjualan dengan berbagai bentuk upaya yang ada dan lokasi dengan indikator yang dimilikinya untuk lebih dioptimalkan pelaksanaannya. Kontribusi sebesar 61,9 persen dari hasil penelitian mendorong perusahaan terhadap tentang pentingnya promosi penjualan dan lokasi sebagai faktor dalam menentukan keputusan pembelian yang dilakukan konsumen.

Promosi penjualan memiliki pengaruh positif dan signifikan terhadap keputusan pembelian. Hasil penelitian yang dilakukan (Rohmah and Lubis, 2018), (Prasetio and Rismawati, 2018), dan (Anggraini and Melinda, 2018) juga memiliki hasil yang sama bahwa keputusan pembelian dipengaruhi oleh promosi penjualan. Hasil positif persamaan regresi menjelaskan bahwa jika promosi penjualan pada PT Bintang Motor Jaya meningkat maka keputusan pembelian menjadi meningkat pula. Upaya promosi penjualan ini terus diupayakan melalui komunikasi yang lebih baik, ajakan kepada konsumen dengan promosi penjualan yang ada, dan pemberian insentif yang menarik.

Lokasi memiliki pengaruh positif dan tidak signifikan terhadap keputusan pembelian. Hasil ini sesuai dilihat dari sisi pengaruh positif tetapi berbeda dengan tingkat signifikannya dari hasil penelitian yang dilakukan (Rizal, Adam and Ibrahim, 2017) dan (Istanti, 2018) yang dalam penemuanya menyatakan lokasi berpengaruh positif dan signifikan terhadap keputusan pembelian. Hasil ini memberikan gambaran pada penelitian ini lokasi tidak menjadi faktor utama dalam keputusan pembelian atau konsumen tidak terpengaruh oleh faktor lokasi dalam memberikan keputusan pembelian. Hasil positif persamaan regresi menjelaskan bahwa jika lokasi pada PT Bintang Motor Jaya semakin baik maka keputusan pembelian juga menjadi bertambah baik sehingga tetap perlu adanya perhatian perusahaan terhadap lokasi dengan selalu mempertahankan lokasi yang strategis, mudah dijangkau konsumen, dan memadainya lahan parkir yang tersedia. 


\section{SIMPULAN DAN REKOMENDASI}

Hasil penelitian memberikan simpulan bahwa secara parsial dikatakan promosi penjualan memiliki pengaruh positif dan signifikan terhadap keputusan pembelian sedangkan lokasi berpengaruh positif tetapi tidak signifikan terhadap keputusan pembelian. Secara simultan keputusan pembelian sepeda motor Honda di PT Bintang Motor Jaya Jakarta dipengaruhi secara positif dan signifikan oleh promosi penjualan dan lokasi dengan F hitung 66,44 dan nilai sig sebesar 0,000. Angka koefisien determinasi 0,619 menunjukkan kontribusi promosi penjualan dan lokasi sebesar 61,9\% sisanya $38,1 \%$ dipengaruhi variabel lain diluar penelitian terhadap keputusan pembelian seperti kualitas produk dan harga. Untuk itu diharapkan ke depannya ada penelitian lebih lanjut. Promosi penjualan di PT Bintang Motor Jaya Jakarta yang sudah baik sebaiknya terus dipertahankan dan perlu ditingkatkan seperti melakukan komunikasi dan ajakan di media online yang ada selain tatap muka seperti pemanfaatan media sosial atau pembuatan website resmi. Selain itu dapat dilakukan pemberian insentif yang disesuaikan segmentasi pasar dan kemampuan perusahaan sebagai contoh memanfaatkan hari istimewa untuk melakukan bentuk promosi penjualan dengan jenis insentif tertentu seperti hari guru dan hari buruh. Untuk lokasi juga tetap diperhatikan dengan mempertahankan lokasi yang strategis dan memperbaki lokasi dengan layanan parkir yang lebih rapi dan aman sehingga memudahkan dan memberi kenyamanan pengunjung saat datang sehingga pada akhirnya menunjang keputusan pembelian.

\section{DAFTAR PUSTAKA}

Abdullah, C. (2018) Pengaruh Promosi Penjualan Dan Lokasi Terhadap Keputusan Pembelian Pada Genesis Coffee. Universitas Pasundan.

Anggraini, C. and Melinda, T. (2018) 'the Effects of Word of Mouth and Sales Promotion', Journal of Entrepreneur and Entrepreneurship, 7(1), pp. 19-26.

Chang, A. Y. P. (2017) 'A Study on the Effects of Sales Promotion on Consumer Involvement and Purchase Intention in Tourism Industry', Eurasia Journal of Mathematics, Science and Technology Education, 13(12), pp. 8323-8330. doi: 10.12973/ejmste/77903.

Fure, H. (2013) 'Lokasi, Keberagaman Produk, Harga, Dan Kualitas Pelayanan Pengaruhnya Terhadap Minat Beli Pada Pasar Tradisional Bersehati Calaca', Jurnal $E M B A, 3(1)$, pp. 273-283. doi: 10.1200/JCO.2014.56.8501.

Istanti, F. (2018) 'Pengaruh Promosi Dan Lokasi Terhadap Keputusan Pembelian Di Indomaret Kecamatan Genteng Surabaya', Jurnal Bisnis \& Teknologi Politeknik NSC Surabaya, 5, pp. 11-16.

Juliandi, A. et al. (2016) Mengolah Data Penelitian Bisnis dengan SPSS. Medan: Lembaga Penelitian dan Penulisan Ilmiah Aqli. 
Eigis Yani Pramularso, Keputusan Pembelian Sepeda Motor Honda

Kotler, P. and Keller, K. L. (2018) Manajemen Pemasaran. Jakarta: PT Indeks.

Prasetio, B. and Rismawati, Y. (2018) 'Pengaruh Promosi Penjualan Terhadap Keputusan Pembelian Pada PT Harjagunatama Lestari (Toserba Borma) Cabang Dakota', Jurnal Ilmiah Manajemen, Ekonomi, \& Akuntansi (MEA), 2(2), pp. 57-65. doi: 10.31955/jimea.vol2.iss2.pp57-65.

Priansa, D. J. (2017) 'Komunikasi Pemasaran Terpadu Pada Era Media Sosial', in. Bandung: Pustaka Setia.

Rizal, F., Adam, M. and Ibrahim, M. (2017) 'Effect of Price, Design and Location on Decision of Purchase and Its Implication on Customer Satisfaction', International Journal of Economics, Commerce and Management, V(12), pp. 345-353.

Rohmah, M. and Lubis, E. E. (2018) 'Pengaruh Promosi Penjualan Terhadap Keputusan Pembelian Konsumen Pada Situs Jual Beli Online Elevenia', Jurnal Online Mahasiswa, 5(2), pp. 1-13.

Rossanty, Y., Nasution, M. D. T. P. and Ario, F. (2018) Consumer Behaviour In Era Millennial. Medan: Lembaga Penelitian dan Penulisan Ilmiah Aqli.

Septiana, A. (2017) Analisis Perilaku Konsumen Dalam Perspektif Ekonomi Kreatif. Pamekasan: Duta Media Publishing.

Yan, R. G. P. S., Repi, A. and Lumanauw, B. (2018) 'Pengaruh Promosi Penjualan Dan Lokasi Terhadap Proses Keputusan Pembelian Kendaraan Bermotor Di PT Tridjaya Mulia Sukses Manado', Jurnal EMBA: Jurnal Riset Ekonomi, Manajemen, Bisnis dan Akuntansi, 6(1). doi: 10.35794/emba.v6i1.18831.

Ye, L. R. and Zhang, H. (2014) 'Sales Promotion and Purchasing Intention: Applying the Technology Acceptance Model in Consumer-To-Consumer Marketplaces', International Journal of Business, Humanities and Technology, 4(3), pp. 1-5. Available at: http://www.ijbhtnet.com/journals/Vol_4_No_3_May_2014/1.pdf.

Zainab, S. (2018) The Influence of Price, Promotion, and Location Toward Customer Decision to Stay at Bossotel Chiangmai Thailand, Faculty of Business Administration. Rajamangala University of Technology Thanyaburi. 